\title{
Direct denitrification in mangrove sediments in Terminos Lagoon, Mexico
}

\author{
Victor H. Rivera-Monroy ${ }^{1,2, *}$, Robert R. Twilley ${ }^{1}$, Ronald G. Boustany ${ }^{3}$, John W. Day ${ }^{2,6}$, \\ Francisco Vera-Herrera ${ }^{4}$, Maria del Carmen Ramirez ${ }^{5}$
}

\author{
'Department of Biology, University of Southwestern Louisiana, Lafayette, Louisiana 70504, USA \\ ${ }^{2}$ Department oi Oceanography and Coastal Sciences, and Coastal Ecology Institute, Louisiana State University, Baton Rouge, \\ Louisiana 70803, USA \\ ${ }^{3}$ National Biological Service, 700 Cajundome Blvd, Lafayette, Louisiana 70506, USA \\ ${ }^{4}$ Sede 'El Carmen', Instituto de Ciencias del Mar y Limnologia, Universidad Nacional Autónoma de Mexico, Cd. del Carmen, \\ Campeche, Mexico 24420 \\ ${ }^{5}$ Facultad de Ciencias Pesqueras, Universidad Autónoma del Carmen, Av. Concordia por 56, Cd. del Carmen, Campeche, \\ Mexico 24100
}

${ }^{6}$ EPOMEX Program, Universidád Autonoma de Campeche, Campeche, Mexico 24000

\begin{abstract}
Rates of direct denitrification were measured using ${ }^{15} \mathrm{~N}$ isotope techniques in intact sediment cores from fringe and basin mangroves in Terminos Lagoon, Mexico. Sediments were injected with ${ }^{15} \mathrm{NO}_{3}{ }^{-}$and the distribution of ${ }^{15} \mathrm{~N}$ was measured over time in the head space, overlying water, and sediments. Experiments included an investigation of spatial variation in denitrification rates by comparing results from the fringe and basin mangroves in the rainy season (July 1991); a second experiment was to determine the effect of 3 different $\mathrm{NO}_{3}^{-}$concentrations $\left(25,100,200 \mu \mathrm{mol}\right.$ core ${ }^{-1}{ }^{15} \mathrm{~N}$ $\mathrm{KNO}_{3}{ }^{-}$) on denitrification rates and was performed in the fringe mangrove during the 'Norte' season (January 1992). Highest ${ }^{15} \mathrm{~N}-\mathrm{N}_{2}$ fluxes were measured in the fringe mangrove at $9.4 \mu \mathrm{mol} \mathrm{m}^{-2} \mathrm{~h}^{-1}$, while denitrification rates in the basin mangrove ranged from 1.9 to $4.5 \mu \mathrm{mol} \mathrm{m} \mathrm{m}^{-2} \mathrm{~h}^{-1}$. ${ }^{15} \mathrm{~N}-\mathrm{N}_{2}$ fluxes in sediment cores from the fringe mangrove were significantly higher $\left(4.5\right.$ to $7.7 \mu \mathrm{mol} \mathrm{m} \mathrm{m}^{-2} \mathrm{~h}^{-1}$ ) in cores enriched with $200 \mu \mathrm{mol}$ core ${ }^{-1}{ }^{15} \mathrm{~N}-\mathrm{KNO}_{3}{ }^{-}$compared to cores enriched with 25 and $100 \mu \mathrm{mol} \mathrm{core}^{-115} \mathrm{~N}$ $\mathrm{KNO}_{3}{ }^{-}\left(<1 \mu \mathrm{mol} \mathrm{m}{ }^{-2} \mathrm{~h}^{-1}\right)$. Most of the applied ${ }^{15} \mathrm{~N}$ was recovered as particulate nitrogen in the sediment and a small fraction reduced to $\mathrm{NH}_{4}{ }^{+}$in both experiments. The low denitrification rates observed in the fringe and basin mangroves indicate that the capacity for sediment denitrification is limited by low $\mathrm{NO}_{3}{ }^{-}$availability. Previous nutrient exchange studies concluded that the fringe mangrove was a 'sink' of $\mathrm{NO}_{3}{ }^{-}$since sediment uptake of $\mathrm{NO}_{3}{ }^{-}$was assumed lost through denitrification. Results from this study show $<10 \%$ of sediment $\mathrm{NO}_{3}{ }^{-}$uptake in fringe mangroves may be lost to denitrification; the remainder being immobilized in the sediment.
\end{abstract}

KEY WORDS: Mangroves - Denitrification - Nitrogen Sediments Rhizophora A Avicennia Terminos L.agoon - Mexico

\section{INTRODUCTION}

Mangroves are a dominant feature of diverse coastal landscapes in the tropics (Por 1984) including river deltas, lagoons, estuaries, and carbonate platforms (Twilley et al. 1995). These forested wetlands are important to the productivity of tropical estuaries (Boto et al. 1985, Lugo et al. 1990, Twilley et al. 1992), yet

·E-mail: riverav@usl.edu there is limited information about nutrient cycling in these intertidal macrophytes. Although nitrogen is an essential element to a variety of biological processes in mangrove forests (Alongi et al. 1992), there are few ecological studies of nitrogen transformations within mangrove ecosystems (Twilley 1988, Alongi et al. 1992). In particular, it is not clear how coupled nitrogen transformations within the forest influence the exchange of nitrogen at the boundary of mangroves with coastal waters. 
A few studies of nitrogen flux between mangroves and coastal waters conclude that mangroves may be a significant sink of dissolved inorganic nitrogen in tidal waters. For example. Walsh (1967) observed that $\mathrm{NO}_{3}$ concentrations entering a mangrove tidal creek in Hawaii, USA, decreased with distance inland, but no nitrogen fluxes were directly measured. Nedwell (1975) reported that about $90 \%$ of $\mathrm{NO}_{3}^{-}$in a polluted station receiving sewage effluent was removed in a mangrove bordered tidal river in Fiji. Rivera-Monroy et al. (1995) measured nitrogen fluxes between Estero Pargo, an unpoliuted tidal creek, and a fringe mangrove forest in Terminos Lagoon, Mexico, reporting that mangrove sediments were a sink of $\mathrm{NO}_{3}^{-}$and $\mathrm{NH}_{4}{ }^{+}$throughout the year. Denitrification, the dissimilatory reduction of $\mathrm{NO}_{3}{ }^{-}$to produce $\mathrm{N}_{2} \mathrm{O}$ and $\mathrm{N}_{2}$, was considered the process that contributed to $\mathrm{NO}_{3}{ }^{-}$loss in these mangrove studies. Yet, there are few direct measurements of denitrification and estimates of how these rates influence the exchange of nitrogen in mangrove forests (e.g Alongi et al. 1992). Denitrification may be an important process that regulates nitrogen flux at the mangrove-estuary boundary (Twilley 1988).

Denitrification is primarily dependent upon anoxic conditions, the presence of an energy source, and availability of $\mathrm{NO}_{3}{ }^{-}$substrate (Mosier \& Schimel 1993). Depending on the $\mathrm{NO}_{3}{ }^{-}$source, there are 2 types of denitrification. Direct denitrification is fueled by $\mathrm{NO}_{3}{ }^{-}$that diffuses into sediments, while coupled denitrification is supported by $\mathrm{NO}_{3}^{-}$produced by nitrification in sediments (Jenkins \& Kemp 1984, Henriksen \& Kemp 1988). Most of the denitrification studies in mangroves have focused on direct denitrification to understand the potential use of mangroves as a natural tertiary treatment of wastewater (Nedwell 1975, Corredor \& Morell 1994). Corredor \& Morell (1994) concluded that sediments in a fringe mangrove in Puerto Rico receiving secondarily treated sewage effluent were capable of denitrifying up to 15 times the normal $\mathrm{NO}_{3}{ }^{-}$concentrations (200 to $1000 \mu \mathrm{M}$ ). However, direct denitrification rates were low in sediments from an unpolluted mangrove tidal channel in Australia (Iizumi 1986) and represented minor losses of nitrugen from the ecosystem (Alongi et al. 1992). Boto \& Wellington (1988) reported that $\mathrm{NO}_{3}{ }^{-}$was actually exported from this system, indicating a source of inorganic nitrogen to coastal waters.

These conflicting results on the denitrifying capacity of mangrove sediments lead to the confusion on the role of mangroves as a $\mathrm{NO}_{3}{ }^{-}$sink (Corredor \& Morell 1994). There is practically no information on direct denitrification in mangroves under natural conditions (i.e. Iizumi 1986), nor how these rates may differ among riverine, fringe, or basin mangroves (Lugo \& Snedaker 1974, Twilley 1988). In our study, we assumed that denitrification could account for the up- take of $\mathrm{NO}_{3}{ }^{-}$observed in flux studies of mangroves by Rivera-Monroy et al. (1995), demonstrating the importance of this transformation to the fate of nitrogen in fringe and basin mangroves. We expected higher denitrification rates in the fringe than in the basin mangroves due to differences in $\mathrm{NO}_{3}{ }^{-}$availability. To test this hypothesis, we measured the effect of different $\mathrm{NO}_{3}{ }^{-}$concentrations on rates of denitrification in intact sediment cores from fringe and basin forests in Estero Pargo during 2 seasons using ${ }^{t 5} \mathrm{~N}$ isotope techniques.

\section{MATERIAL AND METHODS}

Study area. This study was carried out in Terminos Lagoon $\left(18^{\circ} 40^{\prime} \mathrm{N}, 91^{\circ} 30^{\prime} \mathrm{W}\right)$, a large $\left(\sim 1800 \mathrm{~km}^{2}\right)$, shallow coastal lagoon located in the southwestern section of the Yucatan Peninsula in the state of Campeche, Mexico (Fig. 1). The climate of the area is tropical with annual average air temperatures ranging from 18 to $36^{\circ} \mathrm{C}$. Tides are mixed diurnal with a mean tidal range of about $0.5 \mathrm{~m}$. Average annual precipitation $11680 \mathrm{~mm}$ $\mathrm{yr}^{-1}$ ) is seasonal, with a rainy season from June to October, which is associated with frequent tropical convectional rains. The winter storm, or 'Norte' season, is from November to February with strong north winds and frontal rains. The dry season is from March to June. Peak river discharge occurs in the latter months of the rainy season from September to November.

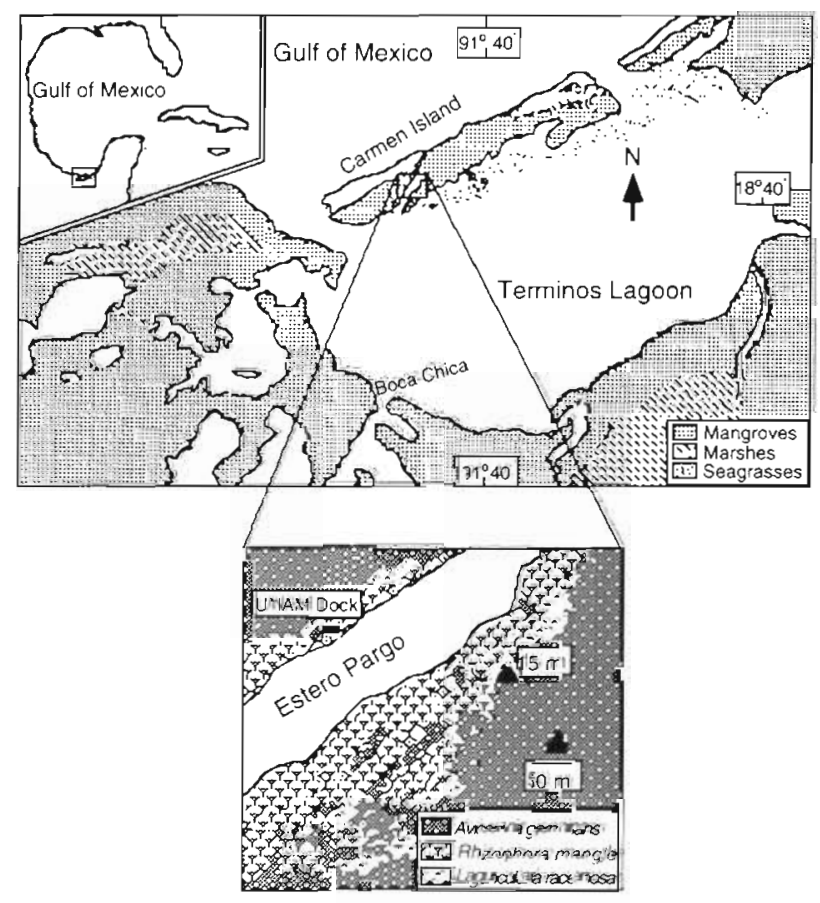

Fig. 1. Location map for sediment cores collected in the fringe and basin mangrove forests in Estero Pargo, Mexico 
The lagoon is bordered almost completely by extensive mangrove forests that are dominated by 3 species: Rhizophora mangle L. (red mangrove), Avicennia germinans L. (black mangrove), and Laguncularia racemosa Gaertn. f. (white mangrove) (Day et al. 1987). Estero Pargo is a tidal creek located on the lagoon side of the barrier island, Isla del Carmen. The forests adjacent to the tidal creek are characteristic of fringe mangroves with regular tidal inundation, while the inland forests are characteristic of basin mangroves which are infrequently flooded (Lugo \& Snedaker 1974, Day et al. 1982). The bulk of the soil material in both mangroves consists of organic matter with many inclusions of fibrous mangrove roots and of coarser woody material. Bulk density in the fringe and riverine mangroves is

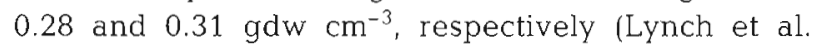
1989). Total nitrogen concentration in sediments reported for the fringe mangrove is $5.7 \mathrm{mg} \mathrm{gdw}^{-1}$ and for the basin mangrove is $9 \mathrm{mg} \mathrm{gdw}^{-1}$ (Lynch 1989). Terminos Lagoon and Estero Pargo have been described in detail elsewhere (Phlegher \& Ayala-Castañares 1971, Ley-Lou 1985, Yañez-Arancibia \& Day 1988).

Experimental design. To evaluate direct denitrification in mangrove sediments, 2 experiments were performed. The first experiment was to investigate spatial variation in denitrification rates by comparing results from the fringe and basin mangroves in the rainy season (July 1991). The second experiment was to determine the effect of different concentrations of $\mathrm{NO}_{3}{ }^{-}$on denitrification rates and was performed in the fringe mangrove during the 'Norte' season (January 1992). Similar concentrations of $\mathrm{NO}_{3}{ }^{-}$were used in the rainy and 'Norte' seasons in the fringe mangrove that allowed a temporal comparison of rates. Experiments were conducted in intact sediment cores collected about $15 \mathrm{~m}$ (fringe) and $50 \mathrm{~m}$ (basin) inland from the tidal creek in Estero Pargo (Fig. 1) .

Four cores were collected from each of the 2 mangroves for the site comparison study, while 6 cores were used in the fringe mangrove for the concentration study. Plexiglas cylinders $(30 \mathrm{~cm}$ long, $15 \mathrm{~cm}$ i.d. and $0.5 \mathrm{~cm}$ wall thickness) were carefully placed on the sediment surface and forced approximately $25 \mathrm{~cm}$ into the sediment. The cores were sampled in close proximity to each other to minimize spatial variability and were considered as replicates. Pneumatophores were present in all cores and precautions were taken to assure that the aerial portions of pneumatophores were not damaged during core sampling. Pneumatophore density was similar in both forests $\left(428 \pm 100 \mathrm{~m}^{-2}\right)$ despite the dominance of Rhizophora mangle trees in the fringe mangrove. After collecting the core, a rubber cap was placed on the core base and secured with 2 aluminum bands. The cores were carefully transported in the dark back to the laboratory. Sediment tempera- ture was measured during core sampling. Floodwater at each site was collected with previously acid-washed $(10 \% \mathrm{HCl} \mathrm{v} / \mathrm{v}) 1 \mathrm{l}$ plastic containers.

Nitrogen-15 enrichment to the cores was $200 \mu \mathrm{mol}$ core $^{-1}{ }^{15} \mathrm{~N}-\mathrm{KNO}_{3}\left(99\right.$ atom $\left.\%{ }^{15} \mathrm{~N}\right)$ for the site comparison experiment in July $1991\left(0.16 \mathrm{~g} \mathrm{~N} \mathrm{~m}^{-2}\right)$. Cores collected in the fringe mangrove in January 1992 were randomly assigned to concentrations of either 25, 100 , or $200 \mu \mathrm{mol}$ core ${ }^{-1}{ }^{15} \mathrm{~N}-\mathrm{KNO}_{3}$ (2 cores per treatment). These enrichments represent $<2 \%$ of the amount added in similar studies of wetland sediments (e.g. $19 \mathrm{~g} \mathrm{~N} \mathrm{~m}^{-2}$, Reedy et al. 1989; $10 \mathrm{~g} \mathrm{~N} \mathrm{~m}^{-2}$, Lindau \& Delaune 1991). Concentrations used in our study were selected to assure that ${ }^{15} \mathrm{~N}$ emission reflected denitrification rates under natural conditions, yet provided a measurable ${ }^{15} \mathrm{~N}$ signal in the cores. Caffrey \& Kemp (1992) used similar ${ }^{15} \mathrm{~N}$ enrichment of $0.15 \mathrm{~g} \mathrm{~m}^{-2}$ to study direct denitrification in subtidal sediments. The isotope solutions were made with filtered $(\mathrm{GF} / \mathrm{F})$ floodwater collected in the field at the same time as the cores. Solutions were injected into each core at the surface, and at 2 and $9 \mathrm{~cm}$ depth to distribute the isotope throughout the core. A water depth of 1 to $2 \mathrm{~cm}$ was maintained over the sediment surface within the cores throughout the experiments with ambient floodwater. After isotope enrichment, the cores were incubated outdoors in the dark using a covered plastic chamber under ambient temperature (mean ambient temperature was $28^{\circ} \mathrm{C}$ ).

In the site comparison experiment, 1 core was removed from the chamber at 1, 3, 5, and $8 \mathrm{~d}$ following ${ }^{15} \mathrm{~N}$-enrichment. At that time pneumatophores were cut about $1 \mathrm{~cm}$ from the top of the core and covered with silicone grease (Corning ${ }^{\otimes}$ ) to minimize altering the normal exchange of gases through these root structures (Scholander et al. 1955, Curran 1985, Nickerson \& Thibodeau 1985, McKee et al. 1988). Production of $\mathrm{N}_{2}$ was trapped in the headspace of each core by placing a plexiglas lid with gasket on the core top which was secured with 6 screws distributed evenly around the lid to form a gas-tight connection. The depth of each headspace was recorded, and zero-time gas samples were collected immediately after the headspace was sealed. Gas samples were taken from the headspace using a gas-tight syringe and hypodermic needle through a rubber septum sealed in the lid. Aliquots of $5 \mathrm{ml}$ were withdrawn at 1 and $10 \mathrm{~h}$, transferred to glass rubber-stoppered Vacutainers ${ }^{\circledR}$ (75 mm long by $10 \mathrm{~mm}$ i.d.), and stored until assay by ${ }^{15} \mathrm{~N}$ mass spectrometry. Vacutainers ${ }^{\otimes}$ were stored immersed in water to prevent contamination of atmospheric gases. After each headspace sampling, an equivalent volume $(5 \mathrm{ml})$ of air was replaced to maintain pressure inside the core, and the core was returned to the incubation chamber. Changes in oxygen concentration in the 
headspace throughout the $10 \mathrm{~h}$ incubation were determined on a second $5 \mathrm{ml}$ aliquot sampled at the same time ${ }^{15} \mathrm{~N}_{2}$ gas samples were taken. Oxygen and $\mathrm{N}_{2}$ concentrations were measured with a gas chromatograph (SRI Instruments Model 8610) equipped with a TCD detector and a CTR dual-phase column (Alltech ${ }^{(B)}$ ) using helium as carrier gas. Oxygen concentrations changed $<14 \%$ in all experiments and $\mathrm{N}_{2}$ concentrations were constant over time (data not shown).

At the end of the $10 \mathrm{~h}$ time series, $50 \mathrm{ml}$ of overlying water was sampled and each core sectioned at approximately $4 \mathrm{~cm}$ intervals to obtain 5 sediment samples per core. Replicate sediment subsamples $(50 \mathrm{~g}$ per sample) were used for extraction of $\mathrm{NH}_{4}{ }^{+}$and $\mathrm{NO}_{3}{ }^{-}$ (Sumi \& Koike 1990) with $2 \mathrm{~N} \mathrm{KCl}(150 \mathrm{ml}$ of $\mathrm{KCl}$ per $50 \mathrm{~g}$ of sediment) for $1 \mathrm{~h}$. Another 2 subsamples $(\sim 35 \mathrm{~g})$ were also taken from each sample for analysis of percent water (dried at $60^{\circ} \mathrm{C}$ for $48 \mathrm{~h}$ ) and bulk density. Dry sediments were ground with mortar and pestle, and assayed for total carbon and nitrogen and ${ }^{15} \mathrm{~N}$ content in 4 subsamples per sample.

Sampling of headspace and sediment during the $\mathrm{NO}_{3}{ }^{-}$concentration study followed a similar procedure as the site comparison study. Headspace samples were collected at 1 and $10 \mathrm{~h}$ periods following ${ }^{15} \mathrm{~N}$ application and after sealing the headspace in each core Headspace sampling was repeated in each core at 1,3 , and $5 \mathrm{~d}$. At the end of the $5 \mathrm{~d}$ incubation the 6 cores were then sectioned and processed for nutrient and ${ }^{15} \mathrm{~N}$ analyses as described above.

Sample analysis. Total carbon and particulate nitrogen (PN) were analyzed with a $\mathrm{LECO}^{\oplus} \mathrm{CHN}$ elemental analyzer. Overlying water and $\mathrm{KCl}$ extracts were analyzed for $\mathrm{NH}_{4}{ }^{+}$(Solórzano 1969) and $\mathrm{NO}_{3}{ }^{-}$(Grasshoff et al. 1983) concentrations. Nitrogen concentrations and sediment densities were used to calculate total $\mathrm{NO}_{3}$, $\mathrm{NH}_{4}{ }^{+}$, and PN per core. Headspace samples were assayed for nitrogen isotopic masses of 28,29 , and 30 by injecting directly into a nuclide Model 3-60-RMS double collector instrument (Premier American Technologies Corp., Bellefonte, PA, USA). Initial air samples obtained at $0 \mathrm{~h}$ during the $10 \mathrm{~h}$ time series sampling were analyzed as a reference gas (background) on the IRMS inlet using the sample inlet (Mulvaney \& Kurtz 1982).

${ }^{15} \mathrm{~N}$ enrichment in overlying water, $\mathrm{KCl}$ extracts and sediment were measured with a JASCO ${ }^{15} \mathrm{~N}$ emission spectrometer. ${ }^{15} \mathrm{NH}_{4}{ }^{+}$and ${ }^{15} \mathrm{NO}_{3}{ }^{-}$in the overlying water and $\mathrm{KCl}$ extracts were isolated by sequential steam distillations using $\mathrm{MgO}$ to raise the $\mathrm{pH}$ above 9.0 (Keeney \& Nelson 1982) following reduction of $\mathrm{NO}_{3}{ }^{-}+$ $\mathrm{NO}_{2}{ }^{-}$to $\mathrm{NH}_{4}{ }^{+}$by Devarda's alloy (Bremer 1965). Carryover between samples was minimized by a distillation of ethanol between each sample (Fiedler \& Proksch 1975). Fifty $\mathrm{ml}$. of the condensate was collected directly onto approximately $0.035 \mathrm{~g}$ of ion sieve (Union Carbide $\# W-85)$. The ion sieve trapped $95 \%$ of the $\mathrm{NH}_{4}{ }^{+}$based on preliminary experiments with $50 \mathrm{ml}$ of distillate. The ion sieve was collected on a $25 \mathrm{~mm} \mathrm{~A} / \mathrm{E}$ filter, dried $\left(60^{\circ} \mathrm{C}\right)$, placed in Petri dishes, and stored in a vacuum desiccator until assay for ${ }^{15} \mathrm{~N}$ content. Recovery of $\mathrm{NH}_{4}{ }^{+}$and $\mathrm{NO}_{3}{ }^{-}$following this distillation procedure averaged $99 \%$ and $75 \%$, respectively. Samples were prepared by first converting organic and inorganic nitrogen to nitrogen gas with a dry microDumas combustion technique (Fielder \& Proksch 1975). Sediment and ion sieve samples were placed in previously degassed $\left(550^{\circ} \mathrm{C}, 12 \mathrm{~h}\right)$ discharge tubes (Pyrex glass $6.0 \mathrm{~mm}$. O.D.) containing $\mathrm{CaO}$ and Cuprox. The tubes were evacuated to $1 \mathrm{mTorr}$, and filled with argon to 1 Torr, and preheated to remove residual water vapor. Tubes were again evacuated to 1 mTorr and argon added to obtain vacuum of 1 Torr. The tubes were sealed and later combusted at $550^{\circ} \mathrm{C}$ for $12 \mathrm{~h}$ and cooled to room temperature for another $12 \mathrm{~h}$. The atom $\%{ }^{15} \mathrm{~N}$ for samples was then determined with a JASCO ${ }^{15} \mathrm{~N}$ analyzer (Model $\mathrm{N}-150$ ). On each sample, 3 scans of the light emission spectra of the 28 and 29 mass were performed. The instrument was calibrated with commercial standards prepared from samples analyzed by mass spectrometry (Japan Spectroscopic Co., Instruction Manual model $N$, 1986). The formula used to calculate atom \% was:

$$
{ }^{15} \mathrm{~N}(\text { atom } \%)=\frac{100}{2 R+1} \text { where } R=\frac{{ }^{14} \mathrm{~N}_{2}}{{ }^{14} \mathrm{~N}{ }^{15} \mathrm{~N}}
$$

(Fielder \& Proksch 1975).

Denitrification rates were calculated using a mass spectrometric procedure developed for determination of ${ }^{15} \mathrm{~N}-\mathrm{N}_{2}$ evolved from sediments treated with ${ }^{15} \mathrm{~N}$ labeled substrates (Mulvaney \& Kurtz 1982, Mulvaney \& Kurtz 1984, Mulvaney \& Boast 1986). The equations used to calculate the total $\mathrm{N}$-flux from the sediment in each core were:

$$
\begin{aligned}
\Delta r & =\left(\frac{{ }^{29} \mathrm{~N}_{2}}{{ }^{28} \mathrm{~N}_{2}}\right)_{\text {sample }}-\left(\frac{{ }^{29} \mathrm{~N}_{2}}{{ }^{28} \mathrm{~N}_{2}}\right)_{\text {reterence }} \\
\Delta r^{\prime} & =\left(\frac{30 \mathrm{~N}_{2}}{{ }^{28} \mathrm{~N}_{2}}\right)_{\text {sample }}-\left(\frac{30 \mathrm{~N}_{2}}{{ }^{28} \mathrm{~N}_{2}}\right)_{\text {teference }} \\
{ }^{15} \mathrm{X}_{\mathrm{N}} & =\frac{2 \frac{\Delta r^{\prime}}{\Delta r}}{1+2 \frac{\Delta r^{\prime}}{\Delta r}} \\
d & =\frac{\Delta r^{\prime}}{\left({ }^{15} \mathrm{X}_{\mathrm{N}}\right)^{2}} \\
\mathrm{~N}_{2} \text { flux } & =\frac{\Delta C}{A \times \Delta t}
\end{aligned}
$$

where $29 / 28$ and $30 / 28$ are ion current ratios determined by the mass spectrometer; 'sample' is air sample 
from a core at some time, $t$, after installation of the core lid; 'reference' is a normal air sample taken from the core immediately after core lid installation; ${ }^{15} \mathrm{X}_{\mathrm{N}}=$ mole fraction of ${ }^{15} \mathrm{~N}$ in the soil $\mathrm{NO}_{3}{ }^{-}$ pool; $d$ is the fraction of total $\mathrm{N}$ gas in the core headspace attributable to denitrification; $A$ is the area of the core; $\Delta t$ is the time the lid covered the core; and $\Delta C$ is the change in the amount of ${ }^{30} \mathrm{~N}_{2}$ and ${ }^{29} \mathrm{~N}_{2}$ in the core headspace during time $t[\Delta \mathrm{C}=$ (total $N_{2}$ in the core headspace $\left.\times d\right)_{t_{1}}-$ (total $\mathrm{N}_{2}$ in the core headspace $\left.\times d\right)_{t_{0}}$ ] (Mosier \& Schimel 1993).

Significant differences in rates of ${ }^{15} \mathrm{~N}-\mathrm{N}_{2}$ production among treatments in the $\mathrm{NO}_{3}{ }^{-}$concentration experiment were determined with a 1-way ANOVA with a level of significance of 0.05 (SAS 1993). A 2-way analysis of variance was used to test differences in sediment $\mathrm{NH}_{4}{ }^{+}$and $\mathrm{NO}_{3}{ }^{-}$concentrations between areas in the site comparison experiment.

\section{RESULTS AND DISCUSSION}

\section{Nutrient concentrations and atom $\%{ }^{15} \mathrm{~N}$ enrichment}

Mean $\mathrm{NH}_{4}{ }^{+}$concentrations were significantly higher $(p<0.05)$ in the fringe than in the basin mangroves in July 1991 (Table 1, Fig. 2). Concentrations ranged from
Table 1. Bulk density ( $\mathrm{BD} \mathrm{g} \mathrm{cm}^{-3}$ ), carbon to nitrogen ratios (C:N), and extractable-N $\left(\mu g \mathrm{gdw}^{-1}\right)$ averaged with depth 10 to $\left.23 \mathrm{~cm}\right)$ in cores from fringe and basin forests incubated at different days in July 1991; mean values $( \pm 1 \mathrm{SD})$

\begin{tabular}{|llcccc|}
\hline $\begin{array}{l}\text { Forest } \\
\text { type }\end{array}$ & Parameter & \multicolumn{5}{c}{ lncubation time $(\mathrm{d})$} \\
\hline Fringe & & 1 & 3 & 5 & 8 \\
& $\mathrm{BD}$ & $0.20(0.01)$ & $0.26(0.01)$ & $0.20(0.01)$ & $0.20(0.01)$ \\
& $\mathrm{C}: \mathrm{N}$ & $25.1(5.1)$ & $22.1(1.7)$ & $19.0(0.61)$ & $21.3(1.5)$ \\
& $\mathrm{NH}_{4}{ }^{+}$ & $35.3(12.2)$ & $28.0(15.5)$ & $37.2(8.11)$ & $37.1(14.5)$ \\
& $\mathrm{NO}_{3}{ }^{-}$ & $6.7(1.4)$ & $4.5(2.9)$ & $7.0(3.01)$ & $11.4(6.0)$ \\
Basin & $\mathrm{BD}$ & $0.22(0.01)$ & $0.4(0.01)$ & $0.22(0.01)$ & $0.60(0.02)$ \\
& $\mathrm{C}: \mathrm{N}^{+}$ & $22.3(1.2)$ & $23.6(1.7)$ & $22.8(1.2)$ & $39.2(16.0)$ \\
& $\mathrm{NH}_{4}{ }^{+}$ & $14.7(5.9)$ & $11.9(10.0)$ & $8.3(6.8)$ & $9.1(1.9)$ \\
& $\mathrm{NO}_{3}$ & $3.7(0.8)$ & $4.1(0.9)$ & $2.4(1.7)$ & $3.2(1.5)$ \\
& & & & & \\
\hline
\end{tabular}

22 to $44 \mu \mathrm{g} \mathrm{gdw}^{-1}$ in the fringe mangrove and from 6 to $18 \mu \mathrm{g} \mathrm{gdw}^{-1}$ in the basin mangrove. There was a decline from $18 \mu \mathrm{g} \mathrm{gdw}^{-1}$ at 0 to $6 \mathrm{~cm}$ to $7 \mu \mathrm{g} \mathrm{gdw}^{-1}$ at 18 to $23 \mathrm{~cm}$ in the basin mangrove (Fig. 2). $\mathrm{NH}_{4}{ }^{+} \mathrm{con}-$ centrations did not show any pattern with depth in the fringe mangrove. Although $\mathrm{NO}_{3}{ }^{-}$concentrations were higher in the fringe than in the basin mangrove, this difference was not significant $(p>0.05)$. Mean $\mathrm{NO}_{3}{ }^{-}$ concentrations ranged from 5.5 to $9.0 \mu \mathrm{g} \mathrm{gdw}^{-1}$ in the fringe mangrove and from 3.5 to $6.5 \mu \mathrm{g} \mathrm{gdw} w^{-1}$ in the basin mangrove. There were no differences in $\mathrm{NO}_{3}{ }^{-}$ concentrations with depth in either area. Particulate nitrogen (PN) concentrations decline with depth in both mangroves (Fig. 3). PN decreased from $11 \mathrm{mg}$ $\mathrm{gdw}^{-1}$ at 0 to $5 \mathrm{~cm}$ to $5.5 \mathrm{mg} \mathrm{gdw}^{-1}$ at 17 to $21 \mathrm{~cm}$ in the
Fig. 2. $\mathrm{NH}_{4}^{+}$and $\mathrm{NO}_{3}^{-}$concentrations with depth in cores from the fringe and basin forest in July 1991
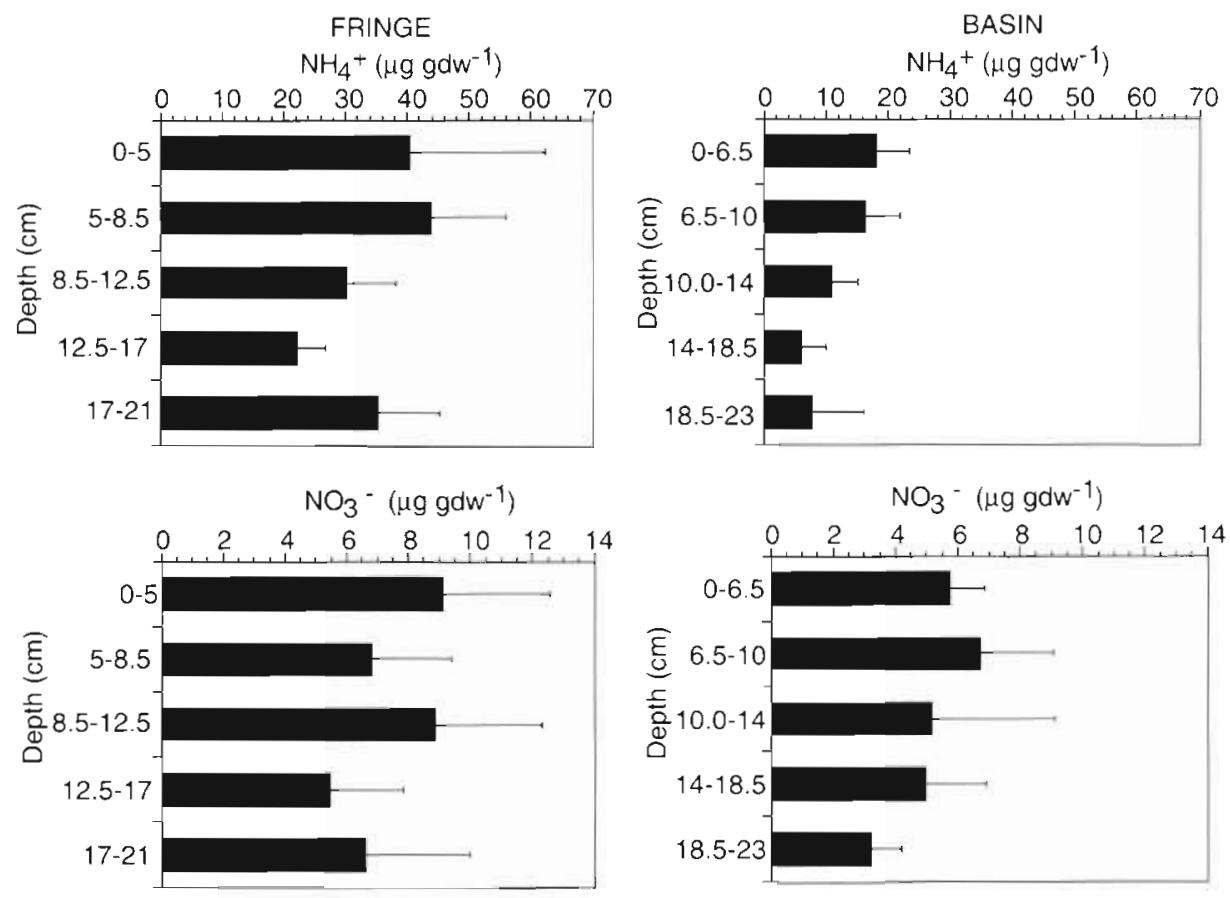

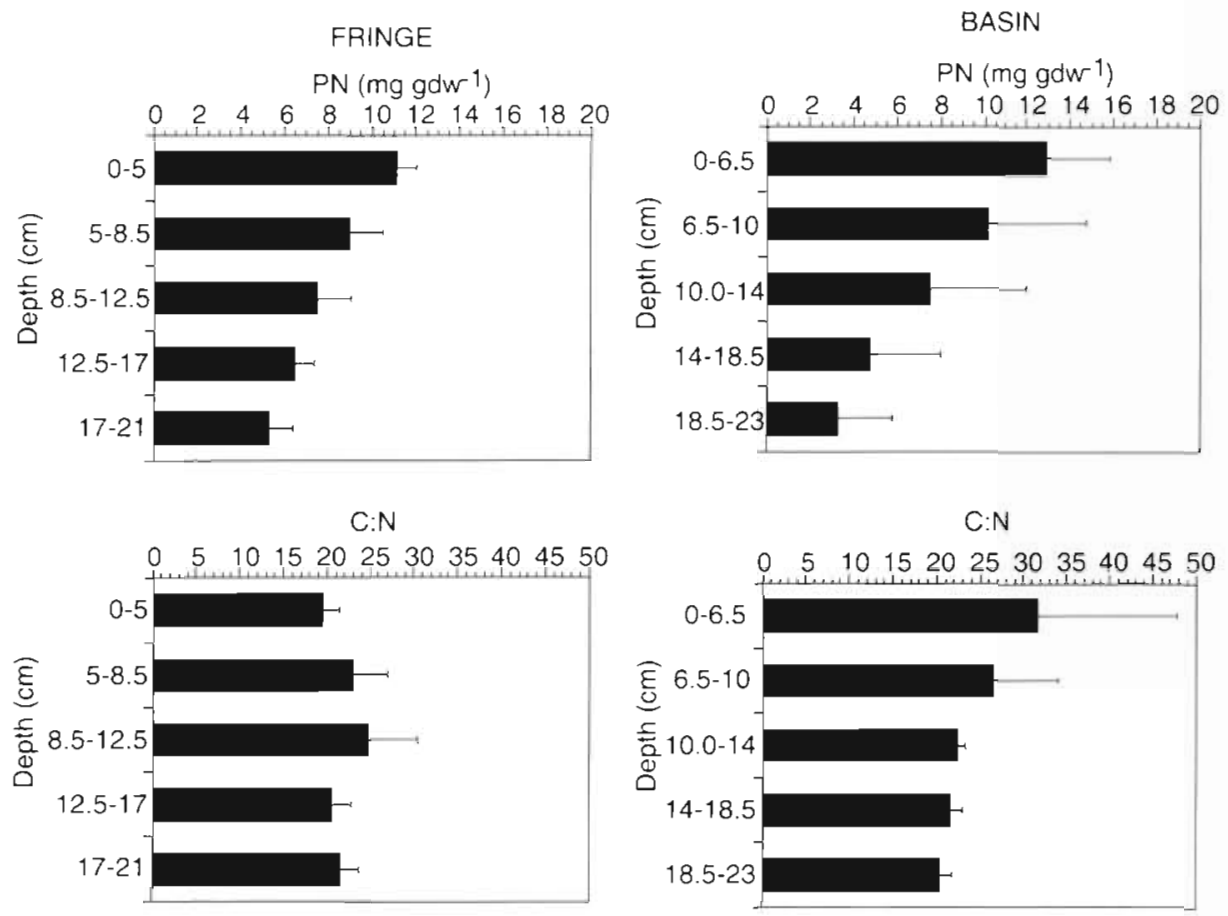

Fig. 3. Particulate nitrogen (PN) and carbon to nitrogen ratios (C:N) with depth in cores from the fringe and basin forest in July 1991

fringe mangrove. In the basin mangrove there was a large variation associated with the mean at each depth, and concentrations declined from $12.5 \mathrm{mg} \mathrm{gdw}^{-1}$ to $3 \mathrm{mg} \mathrm{gdw}^{-1}$. PN concentrations were higher in the top $10 \mathrm{~cm}$ in the basin mangrove than in the fringe mangrove. C:N ratios were not significantly different with depth in either mangrove, although a slightly higher ratio was measured in the basin mangrove in the top $10 \mathrm{~cm}$. Ratios ranged from 19 to 25 in the fringe mangrove and from 21 to 32 in the basin mangrove.

Mean $\mathrm{NH}_{4}{ }^{+}$concentrations were significantly lower $(p<0.05)$ in duplicate cores treated with $25 \mu \mathrm{mol}$ core ${ }^{-1}$ ${ }^{15} \mathrm{~N}-\mathrm{KNO}_{3}$ than in cores treated with 100 and $200 \mu \mathrm{mol}$ core ${ }^{-1}{ }^{15} \mathrm{~N}-\mathrm{KNO}_{3}$. Mean $\mathrm{NO}_{3}{ }^{-}$concentrations were higher in cores amended with $200 \mu \mathrm{mol} \operatorname{core}^{-1}{ }^{15} \mathrm{~N}$ -

Table 2. Bulk density ( $\left.\mathrm{BD} \mathrm{g} \mathrm{cm}^{-3}\right)$, carbon to nitrogen ratios

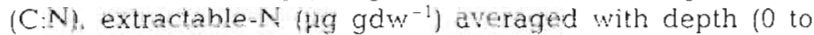
$20 \mathrm{~cm}$ ), and atom $\%$ excess in duplicated cores from a fringe forest enriched with different ${ }^{15} \mathrm{NO}_{3}{ }^{-}$concentrations ( $\mu \mathrm{mol}$ core $^{-1}$ ) in January 1992; mean values $( \pm 1 \mathrm{SD}$ )

\begin{tabular}{|c|c|c|c|}
\hline \multirow[t]{2}{*}{ Parameter } & \multicolumn{3}{|c|}{${ }^{15} \mathrm{NO}_{3}{ }^{-}$treatment concentration } \\
\hline & 25 & 100 & 200 \\
\hline BD & $0.22(0.01)$ & $0.26(0.06)$ & $0.21(0.01)$ \\
\hline$C: N$ & $16.8(0.6)$ & $18.6(2.0)$ & $17.4(0.2)$ \\
\hline $\mathrm{NH}_{4}=$ & $12.9(7.8)$ & $24.5(4.0)$ & $22.9(8.7)$ \\
\hline $\mathrm{NO}_{3}$ & $2.7(1.6)$ & $2.9(1.8)$ & $6.2(3.2)$ \\
\hline atom $\%{ }^{15} \mathrm{NO}_{3}^{-}$ & $0.1(0.2)$ & $0.3(0.1)$ & $0.2(0.1)$ \\
\hline atom $\%{ }^{15} \mathrm{NH}_{4}{ }^{+}$ & $0.1(0.1)$ & $0.4(0.4)$ & $0.2(0.2)$ \\
\hline
\end{tabular}

$\mathrm{KNO}_{3}$, but this difference was not significant (Table 2). There were no differences in mean $\mathrm{C}: \mathrm{N}$ ratios and bulk densities in all treatments (Table 2). Mean $\mathrm{NO}_{3}{ }^{-}$concentrations with depth were higher in cores enriched with $200 \mu \mathrm{mol}$ core ${ }^{-1}{ }^{15} \mathrm{~N}-\mathrm{KNO}_{3}$ with values of 7.5 to $9 \mu \mathrm{gdw}^{-1}$ at 12 to $19 \mathrm{~cm}$, compared to 2 or $3 \mu \mathrm{g} \mathrm{gdw} w^{-1}$ for the other 2 treatments (Fig. 4). Mean atom \% ${ }^{15} \mathrm{NO}_{3}{ }^{-}$ and ${ }^{35} \mathrm{NH}_{4}{ }^{+}$enrichment with depth for all treatments ranged from 0.1 to 0.31 and 0.1 to 0.39 , respectively (Table 2).

\section{${ }^{15} \mathrm{~N}_{2}$ production}

Denitrification rates were extremely low in both the fringe and basin mangroves in July 1991, although sediments from both areas were treated with 200 umol core ${ }^{-1}{ }^{15} \mathrm{~N}-\mathrm{KNO}_{3}$ (Fig. 5). The highest denitrification rate $\left(9.4 \mu \mathrm{mol} \mathrm{m} \mathrm{m}^{-2} \mathrm{~h}^{-1}\right)$ was observed in the fringe mangrove after $3 \mathrm{~d}$ of incubation. This was the only flux of labeled $N_{2}$ observed in this mangrove during the $8 \mathrm{~d}$ incubation period. In contrast, ${ }^{15} \mathrm{~N}_{2}$ fluxes in the basin mangrove declined from $4.5 \mu \mathrm{mol}$ $\mathrm{m}^{-2} \mathrm{~h}^{-1}$ after Day 1 to $1.9 \mu \mathrm{mol} \mathrm{m}^{-2} \mathrm{~h}^{-1}$ at Day 8. No fluxes were observed at this site on Days 3 and 5 . Rates $<5 \mu \mathrm{mol} \mathrm{m} \mathrm{m}^{-2} \mathrm{~h}^{-1}$ are within the lower limits of detection given the analytical sensitivity and size of headspace in these experiments. Thus the presence and absence of rates in Fig 5 indicate the generally low rates of denitrification at the limits of detection at both mangrove sites. 

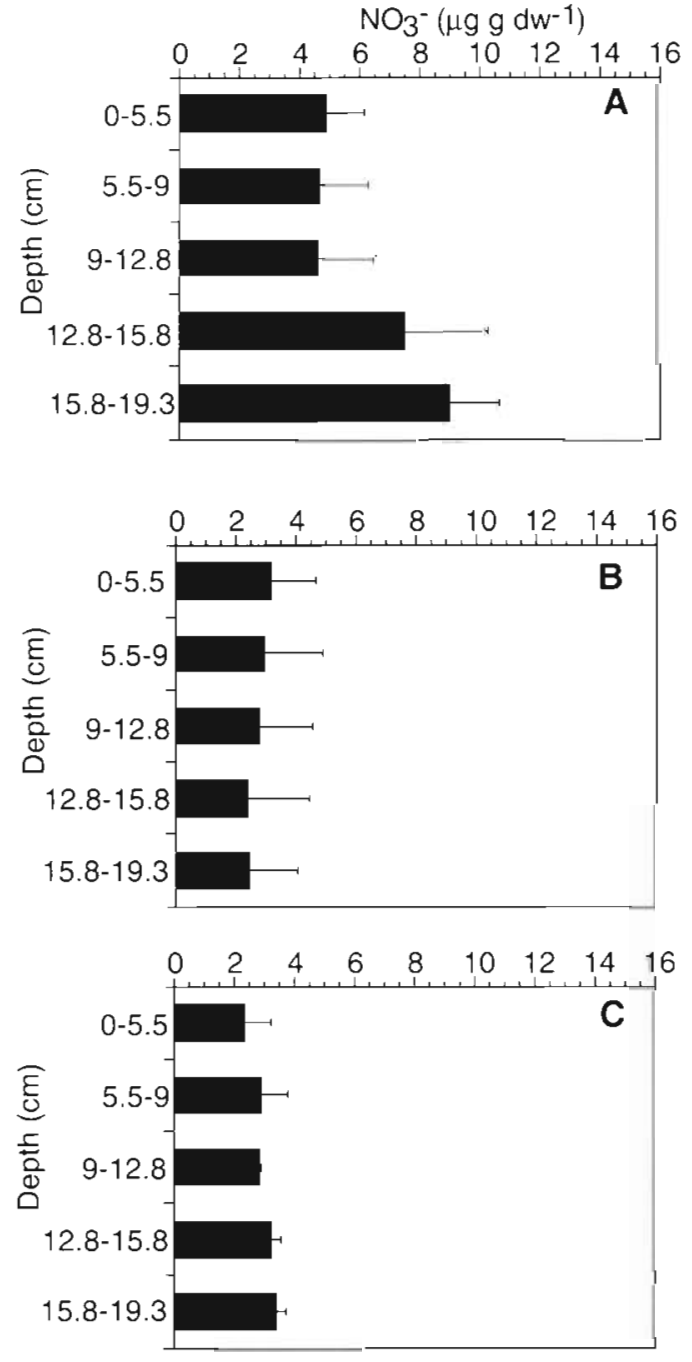

Fig. 4. $\mathrm{NO}_{3}$ concentrations with depth in cores from the fringe forest enriched with different ${ }^{15} \mathrm{~N}-\mathrm{KNO}_{3}$ concentrations in January 1992 as follows: (A) $200 \mu \mathrm{mol}$ core $^{-1}$, (B) $100 \mu \mathrm{mol}$ core $^{-1}$, (C) $25 \mu \mathrm{mol}$ core $^{-1}$

Spatial and temporal variability were confounded in our study since we only analyzed 1 core per time during the incubation in July 1991. Similar concentrations of extractable nitrogen were observed in all cores from the basin mangrove (Table 1), yet the different physical properties of sediments in these experiments may have influenced the timing of ${ }^{15} \mathrm{~N}_{2}$ fluxes. However, despite these problems, it is apparent that denitrification rates are low in the basin forest. On the other hand, similar rates in replicate cores from the enrichment experiment in January 1992 indicate that most of these experimental cores represented homogenous sediment conditions. Results from this experiment also indicate that nitrogen loss through denitrification may be low in the fringe forest. Nielsen et al. (1990) pointed

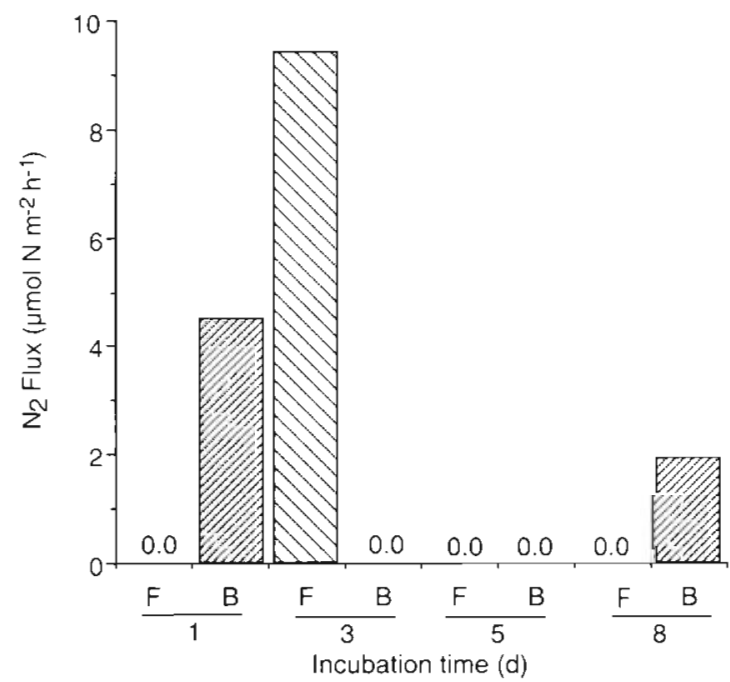

Fig. 5. Denitrification rates at different incubation times in sediment cores from the fringe (F) and basin (B) mangrove forests in Estero Pargo, Mexico in July 1991

out that even when there are high densities of denitrifiers in sediment, diffusion processes influenced by bulk density (Rosenfeld 1979, Mackin \& Aller 1984) can control the supply of electron donors or acceptors, even when such nutrients are present at high concentrations. Lindau \& Delaune (1991) and RisgaardPetersen et al. (1994) found high variation in $\mathrm{N}_{2}$ fluxes among replicates and attributed it to the nonhomogeneity of cores used in their experiments. Kessel et al. (1993) stated that the major problem in estimating $N$ losses by denitrification was the high degree of spatial and temporal variability of this process.

Gas 'entrapment' may contribute from 16 to $41 \%$ of the applied ${ }^{15} \mathrm{~N}$ to the mass balance of nitrogen in permanently flooded sediment systems (Lindau et al. 1988, Katyal et al. 1989, Lindau \& Delaune 1991). These studies found significant reservoirs of ${ }^{15} \mathrm{~N}_{2}$ in the porewaters from 16 to $33 \mathrm{~d}$ following amendments of either urea or ${ }^{15} \mathrm{NO}_{3}{ }^{-}$to the sediment. Estimates using Bunsen solubility coefficients (Weiss 1970) indicate that $\mathrm{N}_{2}$ concentrations are negligible in cores where ${ }^{15} \mathrm{~N}_{2}$ in the headspace was detected. It is not possible to determine if gas 'entrapment' was an important process if the nitrogen flux to the headspace was not in equilibrium with the porewater. This difference between the 2 pools is difficult to evaluate due to the lack of direct ${ }^{15} \mathrm{~N}_{2}$ gas measurements in the pore and overlying water. However, even assuming that ${ }^{15} \mathrm{~N}_{2}$ concentrations in the pore and overlying water are not in equilibrium, the high ${ }^{15} \mathrm{~N}$ concentrations found in the total sediment pool at the end of the incubation period (see below) do indicate that ${ }^{15} \mathrm{~N}$ gas production trapped in the sediment might have been low. 
Pneumatophores inside our cores were cut and sealed with silicone grease to avoid altering exchange of gases and oxidation in the sediment root zone during the $8 \mathrm{~h}$ incubations. Pneumatophores have a significant amount of aerenchyma tissue and are considered as organs responsible for gas exchange between the atmosphere and the internal tissue of mangroves (Scholander et al. 1955). Redox measurements in areas vegetated by this species indicate that this supply of $\mathrm{O}_{2}$ can modify the redox status of normally reduced sediments (Thibodeau \& Nickerson 1986, Carlson \& Yabro 1988, Mckee et al. 1988, McKee 1993). Recent redox measurements in cores from a fringe mangrove in Florida, incubated as described in this study, and with pneumatophore densities similar to the ones observed in our cores, show that redox potentials do not significantly change during $5 \mathrm{~d}$ of incubation (Rivera-Monroy et al. unpubl. results).

\section{Mass balance}

The contribution of $\mathrm{N}_{2}$ production to the mass balance of enriched nitrogen for each core in both experiments was calculated from the cumulative production of $\mathrm{N}_{2}$ during the entire incubation period based on hourly denitrification rates. The recovery of ${ }^{15} \mathrm{~N}$ in the site comparison experiment between fringe and basin mangroves was $<55 \%$ after 8 d of incubation (Table 3 ). These estimates of ${ }^{15} \mathrm{~N}$ recovery do not include ${ }^{15} \mathrm{~N}$ in larger roots and pneumatophores, since these nitrogen pools were not measured. The largest ${ }^{15} \mathrm{~N}$ fraction was measured in the sediments with recovery ranging from 33 to $47 \%$ in the fringe mangrove, and from 38 to $50 \%$ in the basin mangrove. The second largest ${ }^{15} \mathrm{~N}$ fraction was measured in the extractable $\mathrm{NH}_{4}{ }^{+}$pool. ${ }^{15} \mathrm{NH}_{4}{ }^{+}$ represented $<3 \%$ of the total ${ }^{15} \mathrm{~N}$ recovered in the fringe mangrove and $<5 \%$ in the basin mangrove. ${ }^{15} \mathrm{NO}_{3}{ }^{-}$concentrations were $<1 \%$ in both mangroves (Table 3). Similarly, the amount of ${ }^{15} \mathrm{NO}_{3}{ }^{-}$and ${ }^{15} \mathrm{NH}_{4}{ }^{+}$ in the overlying water was almost zero and represented a very small fraction of the total ${ }^{15} \mathrm{~N}$ added in cores. Caffrey \& Kemp (1992) also found a small fraction $(<1 \%)$ of ${ }^{15} \mathrm{~N}$ in the overlying water of vegetated cores. ${ }^{15} \mathrm{~N}_{2}$ in the headspace was detected after $3 \mathrm{~d}$ in the fringe mangrove $(6 \mu \mathrm{mol})$ and after $1 \mathrm{~d}$ in the basin mangrove $(2 \mu \mathrm{mol})$. This flux of nitrogen represented $<3 \%$ of the recovered ${ }^{15} \mathrm{~N}$.

Mass balance in the fringe and basin mangroves suggests that there are other ${ }^{15} \mathrm{NO}_{3}{ }^{-}$sinks. Since we used intact cores, it is possible that some ${ }^{15} \mathrm{NO}_{3}{ }^{-}$was absorbed by the root system. Christensen et al. (1990) pointed out that the presence of plants and their roots can make $\mathrm{NO}_{3}^{-}$unavailable to denitrifying bacteria through uptake and assimilation. Boto et al. (1985) reported that in laboratory experiments $\mathrm{NO}_{3}^{-}$uptake was critical for fine root development of Avicennia marina seedlings. Also, $\mathrm{NO}_{3}{ }^{-}$uptake by algae attached to pneumatophores (Dor \& Levy 1984, Rodriguez \& Stoner 1990) could be another $\mathrm{NO}_{3}^{-}$sink inside the cores. Apparently, 'competition' for $\mathrm{NO}_{3}{ }^{-}$between denitrifiers and uptake by these nitrogen pools might be important in the fringe and basin mangroves during the rainy season.

As in the site comparison study, sediments in the substrate concentration study had the largest accumulation of ${ }^{15} \mathrm{~N}$ (Table 4). The recoveries of excess ${ }^{15} \mathrm{~N}$ for both cores enriched with $200 \mu \mathrm{mol}$ core ${ }^{-1}{ }^{15} \mathrm{~N}-\mathrm{KNO}_{3}$ were 70 and $98 \%$, higher than values in the site comparison study. For the replicated cores enriched with $100 \mu \mathrm{mol}$ core ${ }^{-1}{ }^{15} \mathrm{~N}-\mathrm{KNO}_{3}$ the recoveries were 99 and $104 \%$, and for the cores in the $25 \mu \mathrm{mol}$ core $^{-1}$ ${ }^{15} \mathrm{~N}-\mathrm{KNO}_{3}$ treatment the recoveries were lower at 41 and $80 \%$ (Table 4 ). The second largest fraction of ${ }^{15} \mathrm{~N}$

Table 3. Distribution of applied ${ }^{15} \mathrm{~N}$ ( $\mu \mathrm{mol}$ core ${ }^{-1}$ ) among various forms of nitrogen including mitrogen gas ( $\mathrm{N}_{2}$ ), extractable $\mathrm{N}$ $\left(\mathrm{NH}_{4}{ }^{+}\right.$and $\left.\mathrm{NO}_{3}{ }^{-}\right)$, sedıment nitrogen and total ${ }^{15} \mathrm{~N}$ recovered at different tımes following enrichment as an average with depth $(-0$ to $20 \mathrm{~cm})$ in cores from fringe and basin mangroves in the rainy season, July 1991. Mean $( \pm 1 \mathrm{SD})$. - : no data

\begin{tabular}{|c|c|c|c|c|c|c|c|c|c|c|}
\hline \multirow[t]{2}{*}{ Date } & \multirow{2}{*}{$\begin{array}{c}\text { Forest } \\
\text { type }\end{array}$} & \multirow{2}{*}{$\begin{array}{l}\text { Time } \\
\text { (d) }\end{array}$} & \multirow{2}{*}{$\begin{array}{c}\text { Applied } N \\
\left(\mu \mathrm{mol} \text { core }^{-1}\right)\end{array}$} & \multirow{2}{*}{$\begin{array}{l}\text { Total } N_{2}{ }^{\mathrm{d}} \\
\text { headspace }\end{array}$} & \multicolumn{2}{|c|}{ Extractable $N^{b}$} & \multicolumn{2}{|c|}{ Overlying water } & \multirow[t]{2}{*}{ Sediment ${ }^{a}$} & \multirow[t]{2}{*}{ Total } \\
\hline & & & & & $\mathrm{NH}_{4}{ }^{+}$ & $\mathrm{NO}_{3}$ & $\mathrm{NH}_{4}{ }^{+}$ & $\mathrm{NO}_{3}^{-}$ & & \\
\hline \multirow[t]{4}{*}{4 July 1991} & \multirow[t]{4}{*}{ Fringe } & 1 & 200 & 0 & $3(0.5)$ & $0.06(0.03)$ & - & - & $67(17)$ & 69.3 \\
\hline & & 3 & 200 & 6 & $4(1.3)$ & $0.13(0.02)$ & 0 & 0 & $68(23)$ & 78.1 \\
\hline & & 5 & 200 & 8 & $6(0.6)$ & $0.07(0.05)$ & - & - & $78(29)$ & 92.1 \\
\hline & & 8 & 200 & 8 & $5(1.5)$ & $0.07(0.02)$ & 0 & 0 & $94(35)$ & 107.4 \\
\hline \multirow[t]{4}{*}{7 July 1991} & \multirow[t]{4}{*}{ Basin } & 1 & 200 & 2 & $9(2.7)$ & $0.07(0.03)$ & 0 & 0 & $77(14)$ & 88.1 \\
\hline & & 3 & 200 & 3 & $5(1.3)$ & $0.02(0.01)$ & 0 & 0 & $97(43)$ & 105.0 \\
\hline & & 5 & 200 & 3 & $7(37)$ & $0.20(0.05)$ & - & - & $100(34)$ & 110.2 \\
\hline & & 8 & 200 & 5 & $3(0.7)$ & $0.01(0.00)$ & - & - & $95(16)$ & 103.1 \\
\hline
\end{tabular}


Table 4. Distribution of applied ${ }^{15} \mathrm{~N}\left(\mu \mathrm{mol}\right.$ core $\left.{ }^{-1}\right)$ among various forms of nitrogen including nitrogen gas $\left(\mathrm{N}_{2}\right)$, extractable $\mathrm{N}$ $\left(\mathrm{NH}_{4}{ }^{+}\right.$and $\mathrm{NO}_{3}{ }^{-}$), sediment nitrogen and total ${ }^{15} \mathrm{~N}$ recovered in duplicate cores after a $5 \mathrm{~d}$ incubation following enrichment as an average with depth $(\sim 0$ to $20 \mathrm{~cm})$ in cores from the fringe forest in the 'Norte' season, January 1992. Mean ( \pm 1 SD). -: no data

\begin{tabular}{|c|c|c|c|c|c|c|c|c|}
\hline \multirow{2}{*}{$\begin{array}{l}\text { Applied N } \\
\left(\mu \mathrm{mol} \mathrm{core}^{-1}\right)\end{array}$} & \multirow[t]{2}{*}{ Core ID } & \multirow{2}{*}{$\begin{array}{r}\text { Total } \mathrm{N}_{2}{ }^{\mathrm{a}} \\
\text { headspace }\end{array}$} & \multicolumn{2}{|c|}{ Extractable $\mathrm{N}^{\mathrm{b}}$} & \multicolumn{2}{|c|}{ Overlying water } & \multirow[t]{2}{*}{ Sediment $^{\star}$} & \multirow[t]{2}{*}{ Total } \\
\hline & & & $\mathrm{NH}_{4}{ }^{+}$ & $\mathrm{NO}_{3}^{-}$ & $\mathrm{NH}_{4}{ }^{+}$ & $\mathrm{NO}_{3}^{-}$ & & \\
\hline 200 & 1 & 3.7 & $0.1(0.0)$ & $0.5(0.0)$ & - & - & $135.7(57.4)$ & 140.1 \\
\hline 200 & 2 & 6.5 & $1.5(0.0)$ & $0.4(0.0)$ & - & - & $187.9(45.5)$ & 196.4 \\
\hline 100 & 1 & 0.0 & $13.8(1.4)$ & $3.5(0.5)$ & - & - & $86.7\{42.0\}$ & 104.0 \\
\hline 100 & 2 & 0.5 & $1.1(0.1)$ & $2.1(0.3)$ & - & - & $95.0(40.0)$ & 98.7 \\
\hline 25 & 1 & 0.0 & $0.1(0.0)$ & $0.0(0.0)$ & - & - & $10.3(14.6)$ & 10.4 \\
\hline 25 & 2 & 0.0 & $0.6(0.0)$ & $0.0(0.0)$ & - & - & $19.1(13.0)$ & 19.7 \\
\hline
\end{tabular}

recovered in this experiment was the exchangeable nitrogen pool. The highest recovery $(14 \%)$ of extractable ${ }^{15} \mathrm{NH}_{4}{ }^{+}$was measured in one of the cores enriched with $100 \mu \mathrm{mol}$ core ${ }^{-1}{ }^{15} \mathrm{~N}-\mathrm{KNO}_{3}$; but overall the recovery of ${ }^{15} \mathrm{~N}$ in this pool was $<10 \%$. ${ }^{15} \mathrm{NO}_{3}{ }^{-}$ recoveries in the $\mathrm{KCl}$-extracts for all cores were $<4 \%$. ${ }^{15} \mathrm{~N}_{2}$ in the headspace represented $<3 \%$ of the recovered ${ }^{15} \mathrm{~N} .{ }^{15} \mathrm{NH}_{4}{ }^{+}$and ${ }^{15} \mathrm{NO}_{3}{ }^{-}$in the overlying water were not determined in this experiment due to analytical problems. The recovery of extractable nitrogen pool in the $100 \mu \mathrm{mol}$ core ${ }^{-1}{ }^{15} \mathrm{~N}_{-} \mathrm{KNO}_{3}{ }^{-}$and $200 \mu \mathrm{mol}$ core ${ }^{-1}{ }^{15} \mathrm{~N}_{-} \mathrm{KNO}_{3}{ }^{-}$enrichments may be underestimated due to missing values at some depths. However, this underestimate does not change the overall amount of recovery since low ${ }^{15} \mathrm{~N}$ concentrations were generally found in the extractable nitrogen pool.

Recovery of ${ }^{15} \mathrm{~N}$ in the $\mathrm{NO}_{3}$ - enrichment experiment in January 1992 was $>80 \%$, higher than the site comparison study in July 1991. In both experiments most of the recovered ${ }^{15} \mathrm{~N}$ in all cores was measured in the sediment. The low recovery of ${ }^{15} \mathrm{~N}$ in the extractable pool (which includes pore water ${ }^{15} \mathrm{~N}$ and exchangeable ${ }^{15} \mathrm{~N}$; Mackin \& Aller 1984) indicates that adsorption of ${ }^{15} \mathrm{~N}$ was low. This suggest that a large amount of inorganic nitrogen was probably absorbed by sedimentary bacteria. Davidson et al. (1992) concluded that microbial assimilation of $\mathrm{NO}_{3}^{-}$may be an important pathway for $\mathrm{NO}_{3}^{-}$retention in forest ecosystems. This might be the case in Estero Pargo given the low $\mathrm{NO}_{3}{ }^{-}$concentrations observed in both mangroves (Table 1). When the C:N ratio of substrate is low (<15:1) decomposers are not $N$ limited (Morris 1991), and a net release of inorganic nitrogen to the sediment solution occurs (i.e. mineralization). The high $\mathrm{C}: \mathrm{N}$ ratios measured in sediments in the fringe (19 to 25.1) and basin (22.3 to 39.2) mangroves in Estero Pargo (Table 1) indicate that nitrogen assimilation by bacterial populations in the sediments was probably favored over mineralization.
We used a mass balance approach to estimate potential denitrification rates in comparison to rates calculated from ${ }^{15} \mathrm{~N}-\mathrm{N}_{2}$ production in the cores amended with $200 \mu \mathrm{mol}$ core ${ }^{-1}{ }^{15} \mathrm{~N}-\mathrm{KNO}_{3}$. Assuming that the unrecovered ${ }^{15} \mathrm{~N}$ after $8 \mathrm{~d}$ of incubation is lost to denitrification in the fringe $(92.6 \mu \mathrm{mol})$ and basin $(96.9$ umol) sediments in July 1991, then we would have denitrification rates of $26.5 \mu \mathrm{mol} \mathrm{m} \mathrm{m}^{-2} \mathrm{~h}^{-1}$ and $27.8 \mu \mathrm{mol}$ $\mathrm{m}^{-2} \mathrm{~h}^{-1}$, respectively. Similarly, for replicate cores amended with $200 \mu \mathrm{mol}$ in January 1992, we calculated denitrification rates of 27.5 and $1.6 \mu \mathrm{mol} \mathrm{m} \mathrm{m}^{-2} \mathrm{~h}^{-1}$. It is likely that most of the unaccounted ${ }^{15} \mathrm{~N}$ may have accumulated in other nitrogen pools (i.e. pneumatophores with attached algae) and not lost to denitrification. The high recovery (70 to $100 \%$ ) of ${ }^{15} \mathrm{~N}$ in the sediments and the low denitrification rates also indicate that sedimentary microbes may play an important role in the nitrogen cycle of the fringe and basin mangroves. These results are similar to other studies that demonstrate the significance of microbial immobilization of $\mathrm{NO}_{3}{ }^{-}$in forest soils (Davidson et al. 1992, Hart et al. 1994).

We observed ${ }^{15} \mathrm{NH}_{4}{ }^{+}$in $\mathrm{KCl}$ extracts (Tables 3 \& 4) from sediment in both experiments indicating that $\mathrm{NO}_{3}{ }^{-}$'ammonification', the reduction of $\mathrm{NO}_{3}{ }^{-}$to $\mathrm{NH}_{4}{ }^{+}$ (Koike \& Sorensen 1988), occurred in all the incubations. In contrast to denitrification, which represents a net loss of nitrogen from an ecosystem, $\mathrm{NO}_{3}{ }^{-}$'ammonification' recycles nitrogen within the ecosystem as $\mathrm{NH}_{4}^{+}$. In general, denitrifiers dominate environments in which the $\mathrm{C}: \mathrm{N}$ ratio is low $(<15)$, whereas $\mathrm{NO}_{3}{ }^{-}$is primarily reduced to $\mathrm{NH}_{4}{ }^{+}$in carbon rich environments $(\mathrm{C}: \mathrm{N}>20)$ (Cole \& Brown 1980). Denitrification and $\mathrm{NO}_{3}{ }^{-}$ammonification can occur simultaneously in sediments; the dominance of one process over the other depends on $\mathrm{NO}_{3}{ }^{-}$concentrations and $\mathrm{C}: \mathrm{N}$ ratios of the sediments (Smith et al. 1982, King \& Nedwell 1987, Rehr \& Klemme 1989). $\mathrm{NO}_{3}{ }^{-}$ammonification may be an important nitrogen transformation in mangrove 
ecosystems due to their generally low $\mathrm{NO}_{3}{ }^{-}$sediment concentrations (pore waters $=0$ to $21 \mu \mathrm{M}$; Alongi et al. 1992, Boto 1992) and high C:N ratios (>20) (Boto \& Wellington 1984, Twilley et al. 1986, Steyer 1988 , Lynch et al. 1989, Lugo 1990). Certainly, $\mathrm{NO}_{3}^{-}$reduction to $\mathrm{NH}_{4}{ }^{+}$in temperate coastal sediments is equally or sometimes more important than denitrification (Sørensen 1978, Nishio et al. 1982, Koike \& Sorensen 1988). Despite the potential key role $\mathrm{NO}_{3}{ }^{-}$ammonification might have in the nitrogen cycle in mangrove ecosystems, there are no published references on this process.

\section{Denitrification and $\mathrm{NO}_{3}{ }^{-}$exchange}

${ }^{15} \mathrm{~N}_{2}$ fluxes from sediment cores in the fringe mangrove treated with different concentrations of $\mathrm{NO}_{3}^{-}$ were distinct (Fig. 6). After $1 \mathrm{~d}$ of incubation, denitrification rates ranged from 4.5 to $7.7 \mu \mathrm{mol} \mathrm{m} \mathrm{m}^{-2} \mathrm{~h}^{-1}$ in the 200 umol core ${ }^{-115} \mathrm{~N}-\mathrm{KNO}_{3}$ treatment, but ${ }^{15} \mathrm{~N}_{2}$ production was not observed at 25 and $100 \mu \mathrm{mol} \mathrm{core}^{-1}{ }^{15} \mathrm{~N}$ $\mathrm{KNO}_{3}$ during the initial $24 \mathrm{~h}$ of incubation. Rates declined by approximately $80 \%$ in both cores enriched with $200 \mu \mathrm{mol}$ core ${ }^{-1}{ }^{15} \mathrm{~N}-\mathrm{KNO}_{3}$ after $3 \mathrm{~d}$ of incubation. The only observed production of ${ }^{15} \mathrm{~N}_{2}$ in the other 2 treatments was measured in one core at $100 \mu \mathrm{mol}$ core ${ }^{-1}{ }^{15} \mathrm{~N}-\mathrm{KNO}_{3}$, while no $\mathrm{N}_{2}$ flux was observed during the $5 \mathrm{~d}$ experiment in either of the 2 cores amended with $25 \mu \mathrm{mol}$ core $\mathrm{i}^{-15} \mathrm{~N}-\mathrm{KNO}_{3}$. Thus, rates were significantly higher $(\mathrm{p}<0.05)$ in cores enriched with 200 umol core ${ }^{-1}{ }^{15} \mathrm{~N}-\mathrm{KNO}_{3}$, while there was no significant

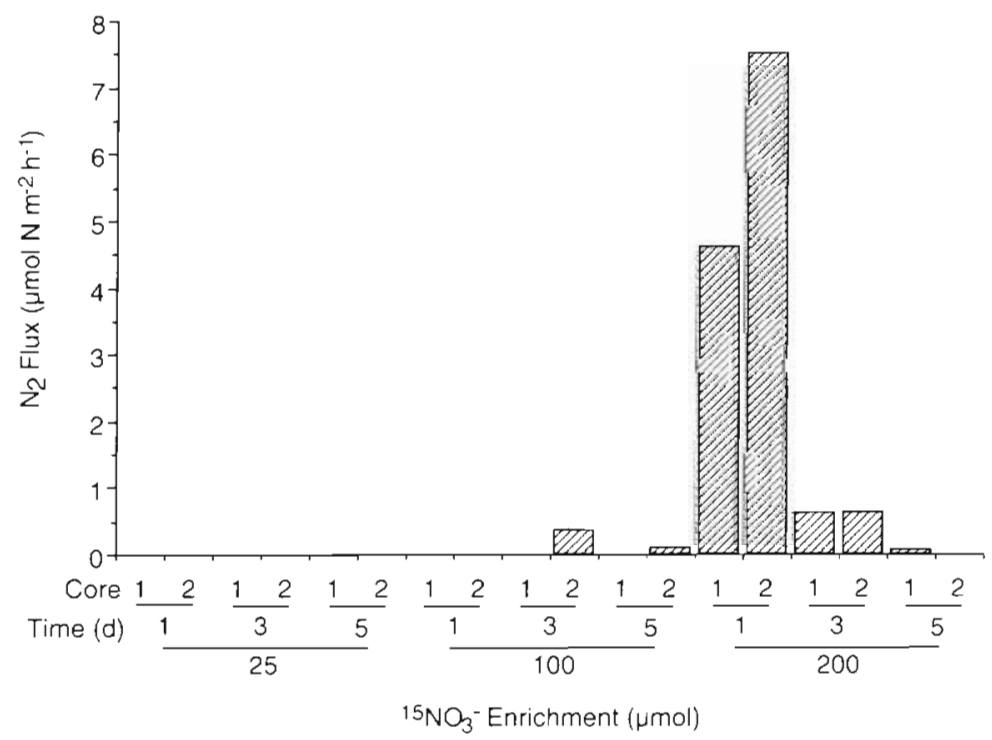

Fig. 6. Denitrification rates at different $\mathrm{NO}_{3}{ }^{-}$enrichments and incubation time in sediment cores collected in the fringe forest in January 1992 in Estero Pargo, Mexico difference in the 25 and $100 \mu \mathrm{mol} \mathrm{core}^{-1}{ }^{15} \mathrm{~N}-\mathrm{KNO}_{3}$ amendments. However, by Day 5 denitrification rates were $0.08 \mu \mathrm{mol} \mathrm{m} \mathrm{m}^{-2} \mathrm{~h}^{-1}$ in one core at $200 \mu \mathrm{mol} \mathrm{core}^{-1}$, and $0.11 \mu \mathrm{mol} \mathrm{m} \mathrm{m}^{-2} \mathrm{~h}^{-1}$ in the $100 \mu \mathrm{mol}$ core $^{-1}$ enrichment.

The spatial and seasonal variation of denitrification in marine sediments has been associated with both the kinetic nature of denitrification capacity and differences in $\mathrm{NO}_{3}{ }^{-}$concentration (Twilley \& Kemp 1986). The kinetic response of denitrification in mangrove sediments to $\mathrm{NO}_{3}{ }^{-}$concentration has been investigated indirectly using $\mathrm{NO}_{3}{ }^{-}$uptake (reduction) from overlying water (Nedwell 1975, Iizumi 1986, Shaiful 1987). The kinetic nature of $\mathrm{NO}_{3}{ }^{-}$uptake (potential denitrification) is described with $\mathrm{K}_{\mathrm{m}}$ values that represent $\mathrm{NO}_{3}{ }^{-}$ concentrations at one-half the saturated uptake (reduction) rates. $K_{m}$ values $(\mu \mathrm{M})$ for mangrove sediments vary from a low of 10 to $69 \mu \mathrm{M}$ for mangroves in Hinchinbrook Island, Australia (Iizumi 1986), to higher values of 167 to $189 \mu \mathrm{M}$ for mangroves in Selangor, Malaysia (Shaiful 1987), and 180 to $600 \mu \mathrm{M}$ in mangroves impacted by sewage enrichment in Fiji (Nedwell 1975) Mean denitrification rate at Hinchinbrook Island was $0.53 \mu \mathrm{mol} \mathrm{m} \mathrm{m}^{-2} \mathrm{~h}^{-1}$ ( Iizumi 1986) compared to a range of 78 to $261 \mu \mathrm{mol} \mathrm{m} \mathrm{m}^{-2} \mathrm{~h}^{-1}$ in the polluted site in Fiji (Nedwell 1975). Maximum $\mathrm{NO}_{3}{ }^{-}$reduction rates ( $\mathrm{V}_{\max }$ using a kinetic approach) in mangrove sediments using a flow through core design were 1320 to $1520 \mu \mathrm{mol} \mathrm{m} \mathrm{m}^{-2} \mathrm{~h}^{-1}$ in 2 mangrove sites in Selangor (Shaiful 1987). The extreme variation in the kinetic nature of potential denitrification $\left(\mathrm{NO}_{3}^{-}\right.$uptake) in mangrove sediments follows the pattern of lower affinity (higher $K_{\mathrm{m}}$ ) and higher capacity (higher $\left.V_{\text {max }}\right)$ in areas of higher carbon and nitrogen supply (Twilley \& Kemp 1986).

The highest rates of $\mathrm{NO}_{3}{ }^{-}$uptake by mangrove sediments in Estero Pargo were about $179 \mu \mathrm{mol} \mathrm{m}{ }^{-2} \mathrm{~h}^{-1}$ (Rivera-Monroy et al. 1995), similar to the medium range of rates measured in mangrove sediments described above by Nedwell (1975). Maximum rates of $\mathrm{NO}_{3}{ }^{-}$uptake in mangrove sediments, using the flume technique, occurred in June 1991 at the beginning of the rainy season and were associated with elevated $\mathrm{NO}_{3}{ }^{-}$concentrations in the river (Rivera-Monroy et al. 1995). Rivera-Monroy et al. (1995) assumed that $\mathrm{NO}_{3}{ }^{-}$reduction in waters flooding the fringe mangrove was lost through denitrification, and concluded that this fringe mangrove was a sink of nitrogen. However, as shown by our ${ }^{15} \mathrm{~N}$ experiments, denitrification accounted for $<10 \%$ of the applied ${ }^{15} \mathrm{NO}_{3}{ }^{-}$, suggesting that this mangrove acts as a 
transformer of nitrogen (Nixon \& Lee 1986) rather than a nitrogen sink.

This is the first work where ${ }^{15} \mathrm{~N}$ techniques have been used to evaluate denitrification rates in mangrove sediments. Addition of inorganic ${ }^{15} \mathrm{NO}_{3}{ }^{-}$to sediment cores from fringe and basin mangroves in Estero Pargo had minor effect on rates of denitrification. Mass balances in both mangroves showed that a large percentage of the added ${ }^{15} \mathrm{NO}_{3}{ }^{-}$was transformed into particulate nitrogen in the sediment, while a small fraction was reduced to $\mathrm{NH}_{4}{ }^{+}$. The dominance of these nitrogen transformations can probably be associated with the low availability of $\mathrm{NO}_{3}{ }^{-}$and the high (>20) C:N ratios of these mangrove sediments. Yet, additional work is needed to evaluate the importance of root and algae uptake in competing with denitrifiers for $\mathrm{NO}_{3}{ }^{-}$. Results from this study indicate that the capacity for denitrification in oligotrophic mangrove sediments is low. The reduction of $\mathrm{NO}_{3}{ }^{-}$in tidal waters in mangroves, particularly at low concentrations, may not necessarily be associated with loss due to denitrification. Thus, studies of nitrogen cycling based on changes in $\mathrm{NO}_{3}{ }^{-}$concentration in tidal waters, such as the studies referred to above, may not accurately describe the function of mangroves as a nitrogen sink.

Studies in coastal marine sediments in temperate regions have shown that nitrification is a major source of nitrate for denitrification (Henriksen \& Kemp 1988, Seitzinger 1988, 1990), but it is not clear if this is the case for tropical and subtropical coastal ecosystems (Alongi et al. 1992). Nitrifying bacteria have been measured in mangrove sediments, but nitrification rates are generally low at $<0.22 \mu \mathrm{mol} \mathrm{g}^{-1} \mathrm{~d}^{-1}$ (Iizumi 1986, Shaiful et al. 1986, Alongi et al. 1992). Shaiful (1987) estimated that nitrate reduction (denitrification) has the capacity to consume 89 to $90 \%$ of the $\mathrm{NO}_{3}{ }^{-}$derived from nitrification. However, direct estimates of coupled nitrification-denitrification in mangroves are needed to evaluate the contribution of this source of $\mathrm{NO}_{3}{ }^{-}$to nitrogen loss in mangrove ecosystems. Spatial and temporal patterns of total denitrification in mangrove sediments of Estero Pargo will depend on determinations of coupled nitrification-denitrification rates to complement the low rates of direct denitrification described in this study.

Acknowledgments. This study was funded by the Program in Science and Technology Cooperation Office of the Science Advisor, U.S. Agency for International Development (Grant DPE-5542-G-SS-8011-00), the U.S. Man and the Biosphere Program, and the International Union for the Conservation of Nature. We received important support for logistıcs and facilities from personnel at the Sede 'El Carmen' - Instituto de Ciencias del Mar y Limnologia of the Universidad Nacional Autonoma de México and the EPOMEX program of the Universidad Autónoma de Campeche. Special thanks to $R$. L Mulvaney for his help in analyzing the ${ }^{15} \mathrm{~N}$ gas samples, and
Jim Lynch, Washington Cárdenas, Shawn Theriot, Claudia Munoz, and Nicole Hairston for their skilled and untiring help in preparing samples for ${ }^{15} \mathrm{~N}$ analysis. Lol-Ha Luna-Leon, Carlos Coronado-Molina, Hernán Alvarez-Guillén, Megan Jones, and Richard Day provided invaluable assistance in the laboratory and the field. This paper is based on a Ph.D. dissertation submitted to the Department of Oceanography and Coastal Sciences, Louisiana State University, USA, by V.H.R.M

\section{LITERATURE CITED}

Alongi DM, Boto KG, Robertson Al (1992) Nitrogen and phosphorous cycles. In: Robertson AI, Alongi DM (eds) Tropical mangrove ecosystems, 41, Coastal and estuarine studies. American Geophysical Union, Washington, DC

Boto KB (1992) Nutrients and mangroves. In: Connell DW, Hawker DH (eds) Pollution in tropical aquatic systems. CRC Press Inc., Boca Raton, p 129-145

Boto KG, Saffigna P, Clough B (1985) Role of nitrate in nitrogen nutrition of the mangrove Avicennia marina. Mar Ecol Prog Ser 21:259-265

Boto KG, Wellington JT (1984) Soil characteristics and nutrient status in a northern Australian mangrove forest. Estuar coast Shelf Sci 7:61-69

Boto KG, Wellington JT (1988) Seasonal variation in concentrations and fluxes of dissolved organic and inorganic materials in a tropical tidally-dominated mangrove water waterway. Mar Ecol Prog Ser 50:151-160

Bremner JM (1965) Inorganic forms of nitrogen. In: Black CA et al. (eds) Methods of soil analysis, part 2.9. Am Soc of Agron, Madison, WI, p 1179-1237

Caffrey JM, Kemp WK (1992) Influence of the submersed plant, Potamogeton perfoliatus, on nitrogen cycling in estuarine sediments. Limnol Oceanogr 37:1483-1495

Carlson PR, Yabro LA (1988) Physical and biological control of mangrove pore water chemistry. In: Hook DD et al. (eds) The ecology and management of wetlands, Vol 1, Ecology of wetlands. Timber Press, Portland, OR, p 112-132

Christensen PB, Nielsen LP, Sorensen J, Revsbech NP (1990) Denitrification in nitrate-rich streams; diurnal and seasonal variation related to benthic oxygen metabolism. Limnol Oceanogr 35:640-651

Cole JA, Brown CM $\{1980\}$ Nitrite reduction to ammonia by fermentative bacteria: a short circuit in the biological nitrogen cycle. FEMS Microbiol Lett 7:65-72

Corredor JE, Morell MJ (1994) Nitrate depuration of secondary sewage effluents in mangrove sediments. Estuaries 17:295-300

Curran M (1985) Gas movements in the roots of Avicennia marina (Forsk.) Vierh. Austr J Plant Physiol 12:97-108

Davidson EA, Hart SC, Firestone MK (1992) Internal cycling of nitrate in soils of a mature coniferous forest. Ecology $73: 1148-1156$

Day JW, Conner WH, Ley-Lou F, Day RH, Navarro AM (1987) The productivity and composition of mangrove forests, Laguna de Terminos, Mexico. Aquat Bot 27:267-284

Day JW, Day RH, Barreiro MT, Ley-Lou F, Madden CJ (1982) Primary production in the Laguna de Terminos, a tropical estuary in the southern Gulf of Mexico. Oceanol Acta 5: $269-276$

Dor I, Levy 1 (1984) Primary productivity of the benthic algae in the hard-bottom mangal of Sinai. In: Por FD, Dor I (eds) Hydrobiology of the mangal. 20, Development in hydrobiology. Dr W Junk Publishers, The Hague, p 179-191

Fiedler R, Proksch G (1975) The determination of nitrogen-15 
by emission and mass spectrometry in biochemical analysis: a review. Anal Chim Acta 78:1-62

Grasshoff K, Erhardt M, Kremling K (1983) Methods of seawater analysis. Verlag Chemie, Weinheim

Hart SC, Nason GE, Myrold DD, Perry DA (1994). Dynamics of gross nitrogen transformation in an old-growth forest: the carbon connection. Ecology 75:880-891

Henriksen K, Kemp WM (1988) Nitrification in estuarine and coastal marine sediments. In: Blackburn $T H$, Sorensen $J$ (eds) Nitrogen cycling in coastal marine environments, 33. SCOPE, John Wiley and Sons, New York, p 207-249

lizumi H (1986) Soil nutrient dynamics. In: Cragg S, Polunin $\mathrm{N}$ (eds) Workshop on mangrove ecosystem dynamics. UNDP/UNESCO Regional Project (RAS/79/002), New Delhi, p 171-180

Jenkins MC, Kemp WM (1984) The coupling of nitrification and dentrification in two estuarine sediments. Limnol Oceanogr 29:609-619

Katyal JC, Holt LS, Gadalla AM (1989) A method to determine soil-entrapped denitrification products in submerged soils. Soil Sci Soc Am J 53:296-297

Keeney DR, Nelson DW (1982) Nitrogen - inorganic forms. In: Page AL, Miller RH, Keeny DR (eds) Methods of soil analysis, Part 2. Chemical and microbiological properties. ASA-SSSA, Madison, WI, p 643-698

Kessel CV, Pennock DJ, Farrel RE (1993) Seasonal variations in denitrification and nitrous oxide evolution at the landscape scale. Soil Sci Soc Am J 57:988-995

King D, Nediwell DB (1987) The adaptation of nitrate reducing bacterial communities in estuarine sediments in response to overlying nitrate load. FEMS Microbiol Ecol 45:15-26

Koike I, Sørensen J (1988) Nitrate reduction and dentrification in marine sediments. In: Blackburn TH, Sørensen J (eds) Nitrogen cycling in coastal marine environments. John Wiley \& Sons, Ltd, New York, p 251-273

Ley-Lou $F$ (1985) Aquatic primary productivity, nutrient chemistry, and oyster community ecology in a mangrove bordered tidal channel, Laguna de Terminos, Mexico. MSc thesis, Louisiana State University, Baton Rouge

Lindau CW, Delaune RD (1991) Dinitrogen and nitrous oxide emission and entrapment in Spartina alterniflora saltmarsh soils following addition of $\mathrm{N}-15$ labeled ammonium and nitrate. Estuar coast Shelf Sci 32:161-172

Lindau CW, Patrick WH, DeLaune RD, Reddy KR, Bollich PK (1988) Entrapment of nitrogen-15 dinitrogen during soil denitrification. Soil Sci Soc Am J 52:538-540

Lugo AE (1990) Fringe wetlands. In: Lugo AE, Brinson $M$, Brown $S$ (eds) Ecosystems of the world: forested wetlands. Elsevier, Amsterdam p 143-169

Lugo AE, Brown S, Brinson MM (1990) Concepts in wetland ecology. In: Lugo AE, Brinson M, Brown S (eds) Ecosystems of the world: forested wetlands. Elsevier. Amsterdam, p 53-85

Lugo AE, Snedaker SC (1974) The ecology of mangroves. A Rev Ecol Syst 5:39-64

Lynch JC (1989) Sedimentation and nutrient accumulation in mangrove ecosystems of the Gulf of Mexico. MSc thesis, The University of Southwestern Louisiana, Lafayette

Lynch JC, Meriwether JR, McKee BA, Vera-Herrera F, Twilley RR (1989) Recent accretion in mangrove ecosystems based on ${ }^{137} \mathrm{Cs}$ and ${ }^{210} \mathrm{~Pb}$. Estuaries 12:284-299

Mackin JE, Aller RC (1984) Ammonium adsorption in marine sediments. Limnol Oceanogr 29:250-257

McKee KL (1993) Soll physiochemical patterns and mangrove species distribution - reciprocal effects? J Ecol 81:477-487

McKee KL, Mendelssohn IA, Hester MW (1988) Reexamination of pore water sulfide concentrations and redox poten- tials near the aerial roots of Rhizophora mangle and Avicennia germmans. Am J Bot 75:1352-1359

Morris JT (1991) Effects of nitrogen loading on wetland ecosystems with particular reference to atmospheric deposition. A Rev Ecol Syst 22:257-279

Mosier AR, Schimel DS (1993) Nitrification and denitrifcation. In: Knowles R, Blackburn TH (eds) Nitrogen isotope techniques. Isotopic techniques in plant, soil, and aquatic biology. Academic Press, San Diego, p 181-208

Mulvaney RL, Boast CW (1986) Equations for determunation of nitrogen-15 labeled dinitrogen and nitrous oxide by mass spectrometry. Soil Sci Soc Am J 50:360-363

Mulvaney RL, Kurtz LT (1982) A new method for determination of ${ }^{15} \mathrm{~N}$-labeled nitrous oxide. Soil Sci Soc Am J 46 $1178-1184$

Mulvaney RL, Kurtz LI (1984) Evolution of dinitrogen and nitrous oxide from nitrogen-15 fertilized soil cores subjected to wetting and drying cycles. Soil Sci Soc Am J 48: $596-602$

Nedwell DB (1975) Inorganic nitrogen metabolism in a eutrophicated tropical mangrove estuary. Water Res 9: $221-231$

Nickerson NH, Thibodeau FR (1985) Association between pore water sulfide concentrations and the distribution of mangroves. Biogeochem 1:183-192

Nielsen LP, Christensen PB, Revsbech NP (1990) Denitrification and photosynthesis in stream sediment studied with microsensor and whole-core techniques. Limnol Oceanogr 35:1135-1144

Nishio T, Koike I, Hattori A (1982) Denitrification, nitrate reduction, and oxygen consumption in coastal and estuarine sediments. Appl environ Microbiol 43:648-653

Nixon SW, Lee V (1986) Wetlands and water quality: a regional review of recent research in the United States on the role of freshwater and saltwater wetlands as sources, sinks, and transformers of nitrogen, phosphorous, and various heavy metals. Contract No. DACW39-83-M-0366, US Army Engineer Waterways Experiment Station, Vicksburg, MS

Phleger FB, Ayala-Castanares A (1971) Processes and history of Laguna de Terminos, Mexico. Bull Am Ass Petrol Geol 55:2130-2140

Por FD (1984) The ecosystem of the mangal: general considerations. In: Por FD, Dor I (eds) Hydrobiology of the mangal: the ecosystem of the mangrove forest. 20, Developments in hydrobiology. Dr W Junk Publishers, The Hague, p 1-14

Reedy KR, Patrıck WH, Lindau CW (1989) Nitrification-denitrification at the plant root-sediment interface in wetlands Limnol Oceanogr 34:1004-1013

Rehr B, Klemme JH (1989) Competition for nitrate between denitrifying Pseudomonas stutzeri and nitrate ammonifying enterobacteria. FEMS Microbiol Ecol 62:51-64

Risgaard-Petersen N, Rysgaard S, Nielsen LP, Revsbech NP (1994) Diurnal variation of denitrification and nitrification in sediments colonized by benthic microphytes. Limnol. Oceanogr 39.573-579

Rivera-Monroy VH, Day WJ, Twilley RR, Vera-Herrera F Coronado-Molina C (1995). Flux of nitrogen and sediment in a fringe mangrove forest in Terminos Lagoon, Mexico. Estuar coast Shelf Sci 40:139-160

Rodriguez C. Stoner A (1990) The epiphyte community of mangrove roots in a tropical estuary: distribution and biomass. Aquat Bot 36:117-126

Rosenfeld JK (1979) Ammonium adsorption in nearshore anoxic sediments. Limnol Oceanogr 24:356-364

SAS (1993) JMP ${ }^{\oplus}$ user's guide. SAS Institute, Cary, NC 
Scholander PF, van Dam L, Scholander SI (1955) Gas exchange in the roots of mangroves. Am J Bot 42:92-98

Seitzinger SP (1988) Denitrification in freshwater and coastal marine sediments: ecological and geochemical significance. Limnol Oceanogr 33:702-724

Seitzinger SP (1990) Denitrification in aquatic sediments. In Revsbech NP, Sørensen J (eds) Denitrification in soil and sediments. Plenum, New York, p 301-322

Shaiful AAA (1987) Nitrate reduction in mangrove swamps. Malaysian appl Biol 16:361-367

Shaiful AAA, Abdul Manan DM, Ramli MR, Veerasamy R (1986) Ammonification and nitrification in wet mangrove soils. Malays J Sci $8: 47-56$

Smith CJ, Delaune RD, Patrick WH (1982) Nitrate reduction in Spartina alterniflora marsh soil. Soil Sci Soc Am J 46 : $748-750$

Solórzano L. (1969) Determination of ammonia in natural waters by the phenolhypochlorite method. Limnol Oceanogr $14: 799-801$

Sørensen J (1978) Capacity for denitrification and reduction of nitrate to ammonia in a coastal marine sediment. Appl environ Microbiol 35:301-305

Steyer GD (1988) Litter dynamics and nitrogen retranslocation in three types of mangrove forests in Rookery Bay, Florida. MSc thesis, The University of Southwestern Louisiana, Lafayette

Sumi T, Koike I (1990) Estimation of ammonification and ammonium asimilation in surficial coastal and estuarine sediments. Limnol Oceanogr 35:270-286

Thibodeau FR, Nickerson NH (1986) Differential oxidation of mangrove substrate by Avicennia germinans and Rhizophora mangle. Am J Bot 73:512-516

This article was presented by S. Y. Newell (Senior Editorial Advisor), Sapelo Island, Georgia, USA
Twilley RR (1988) Coupling of mangroves to the productivity of estuarine and coastal waters. In: Jansson $B O$ (ed) Coastal-offshore ecosystems: interactions. 22, Lecture notes on coastal and estuarine studies. Springer-Verlag, Berlin, p 80-155

Twilley RR, Chen RH, Hargis T (1992) Carbon sinks in mangroves and their implications to carbon budget of tropical ecosystems. Water Air Soil Pollut 64:265-288

Twilley RR, Kemp WM (1986) Factors controlling the variability of denitrification potentials in Chesapeake Bay sediments. In Wolfe DA (ed) Estuarine variability. Academic Press, Orlando, p 277-293

Twilley RR, Lugo AE, Patterson-Zucca C (1986) Production, standing crop, and decomposition of litter in basin mangrove forests in southwest Florida. Ecology 67:67-683

Twilley RR, Snedaker SC, Yañez-Arancibia A, Medina E (1995) Biodiversity and ecosystem processes in tropical estuaries: perspectives from mangrove ecosystems. In: Mooney $\mathrm{H}$, Cushman $\mathrm{H}$, Medina $\mathrm{E}$ (eds) Biodiversity and ecosystem functions: a global perspective. John Wiley and Sons, New York (in press)

Walsh GE (1967) An ecological study of a Hawaiian mangrove swamp. In: Lauff GH (ed) Estuaries. American Association for the Advancement of Science, Washington, DC, $p$ $420-431$

Weiss RF (1970) The solubility of nitrogen, oxygen and argon in water and seawater. Deep Sea Res 17:721-735

Yañez-Arancibia A, Day JW (1988) Ecological characterization of the Terminos Lagoon. In: Yanez-Arancibia A, Day JW (eds) Ecology of coastal ecosystems in the Southern Gulf of México: the Terminos Lagoon region. UNAMI Press, Mexico, p 1-26

Manuscript first received: January 17, 1995

Revised version accepted: May 15, 1995 